\title{
Long term outcome of gonadotrophin releasing hormone analogue therapy in Sri Lankan children with central precocious puberty
}

\author{
*K S H de Silva ${ }^{1}$, M E C Muhandiram², N S Gunawardena ${ }^{3}$
}

Sri Lanka Journal of Child Health 2015; 44(2): 82-87

\begin{abstract}
Introduction: Central precocious puberty (CPP) needs treatment to minimise the psychosocial impact and optimize the auxological outcome.
\end{abstract}

Objective: To analyse the growth pattern and outcome of gonadotrophin releasing hormone analogue (GnRHa) therapy in a cohort of children with CPP

Method: Heights were serially recorded, skeletal age monitored and height velocities calculated in children with CPP prospectively followed up from presentation to cessation of therapy with GnRHa. The response to treatment was assessed as the height standard deviation scores (SDS), ratio of chronological age to bone age and reduction of height velocity with treatment and the significance was determined using the paired ' $t$ ' test and ANOVA. Their heights when last seen were compared with their predicted mature heights and target heights which were calculated based on the bone age prior to treatment and the parents' heights respectively.

Results: There were 9 patients ( 8 girls) with a mean age of 56.4 (19.1) and 124.2 (15.2) months at onset and completion of treatment respectively. There was a significant reduction in the height SDS, bone age acceleration and height velocity with treatment. The heights at final assessment were acceptable for the national average in the majority.

Conclusion: There was a significant reduction in the height SDS, bone age acceleration and height velocity in the cohort of children with CPP treated with a GnRHa.

${ }^{1}$ Professor in Paediatrics, Faculty of Medicine, University of Colombo and Consultant Paediatrician, Lady Ridgeway Hospital, Colombo, ${ }^{2}$ Intern Medical Officer, Lady Ridgeway Hospital, Colombo, ${ }^{3}$ Professor in Community Medicine, Faculty of Medicine, University of Colombo

*Correspondence: shamyadesilva@hotmail.com

(Received on 6 June 2014: Accepted after revision on 18 July 2014)
(Key words: Long term follow up, central precocious puberty, gonadotrophin releasing hormone analogue therapy, Sri Lankan children).

\section{Introduction}

Gonadotrophin releasing hormone dependent precocious puberty or central precocious puberty (CPP) is suspected when secondary sexual characteristics appear before 8 years and 9 years respectively in a girl or boy ${ }^{1,2,3}$. Menarche in a very young girl is a cause of immense psychological distress to the parents and family and is socially unacceptable. A young boy manifesting symptoms and signs of puberty is equally distressing to the parents and their behaviour may be disruptive at school. Untreated CPP will also result in a progressive advancement in skeletal maturation with premature epiphyseal closure, ultimately compromising the final adult height. Therefore, treatment is indicated with a gonadotrophin releasing hormone analogue (GnRHa) to block the pituitarygonadal axis and arrest the progression of puberty. This will result in slowing skeletal maturation thus reducing the growth velocity thereby preserving the growth potential ${ }^{1,2,3}$. This is an analysis of the growth pattern and outcome of long-acting GnRHa therapy in a cohort of children with CPP and the first such report from Sri Lanka.

\section{Objective}

To analyse the growth pattern and outcome of GnRHa therapy in a cohort of children with CPP

\section{Method}

Data, recorded prospectively, of a cohort of children with CPP presenting to a single ward at the Lady Ridgeway Hospital, Colombo over approximately 12 years, was analysed at the cessation of therapy. CPP was confirmed by biochemical, radiological and ultrasound investigations. The decision to treat was based on published criteria ${ }^{1}$ and after discussing same with the parents. All the children had neuro-imaging prior to commencing therapy. Treatment was with a gonadotrophin releasing hormone analogue, Goserellin acetate $3.6 \mathrm{mg}$, given 4 weekly 
subcutaneously. They were followed up at regular intervals in the ward and the relevant anthropometric data and clinical features were recorded prospectively by the chief investigator. Serial measurements of the standing height were taken using a wall-mounted stadiometer as per published instructions ${ }^{4}$. The skeletal maturation was monitored periodically using the Greulich-Pyle Atlas 5 .

The patients' height standard deviation scores (SDS) prior to treatment and at the time of discontinuing therapy were calculated using the Learning Management Systems (LMS) growth programme version 2.69 (2010) using World Health Organisation (WHO) Child and 5-19 growth reference standards (2006/2007). The initial skeletal maturation and subsequent response to treatment were documented as chronological age/bone age $[\mathrm{CA} / \mathrm{BA}]^{6}$. The paired ' $t$ ' test was used to determine the significance of the above findings. The pre-treatment height velocity and velocity during the first and last year of treatment were calculated and were compared using the $\mathrm{F}$ test or the analysis of variance (ANOVA).

The pre-treatment predicted mature heights $(\mathrm{PMH})$ were calculated ${ }^{4}$ and were compared with the heights at the most recent assessment and with the expected target heights of the children based on their parents' heights. Calculation of the PMH is based on the BA prior to treatment which should be more than 7 years ${ }^{4}$. The BA is unreliable for predicting height gain after treatment has been started ${ }^{1}$. Predicted mature height could not be calculated in one child (Serial no: 4) as her bone age was less than 7 years when treatment was commenced ${ }^{2,4}$. We used the column 'advanced' when the bone age advancement was greater than 1 year $^{4}$ to assess the PMH. The target height $(\mathrm{TH})$ or mid-parental height was calculated thus ${ }^{7}$ :

Girl $\rightarrow$ mother's height + father's height $-13.0 \mathrm{~cm} / 2$ Boy $\rightarrow$ mother's height + father's height $+13.0 \mathrm{~cm} / 2$ Target height range was taken as the $T H \pm 8.5 \mathrm{~cm}^{7}$.

Discontinuation of therapy was done taking into consideration the wishes of the parents and child, onset of puberty in the peers and age of menarche of the mother and sisters of the girls and at an appropriate age of the child for pubertal onset ${ }^{1,8}$.

\section{Results}

There were 9 patients ( 8 girls) who had completed therapy. The age at onset of treatment ranged from 19 months $(1 \mathrm{yr} 7 \mathrm{~m})$ to 81 months (6yr $9 \mathrm{~m})$ with a mean (SD) of 56.4 (19.07) months. They were 88 to 142 months $(7 \mathrm{yr} 4 \mathrm{~m}$ to $11 \mathrm{yr} 10 \mathrm{~m})$ at the completion of therapy with the duration of treatment being 44 to 101 months (3yr $8 \mathrm{~m}$ to $8 \mathrm{yr} 5 \mathrm{~m}$ ) with a mean of 68 months $(5 \mathrm{yr} 8 \mathrm{~m})$ as shown in Table 1.

Table 1: Description of patients of the study sample ( $n=9)$

\begin{tabular}{|c|c|c|c|}
\hline $\begin{array}{c}\text { Serial number and } \\
\text { gender }\end{array}$ & $\begin{array}{c}\text { Age at onset of treatment } \\
\text { (months) }\end{array}$ & $\begin{array}{c}\text { Age at completion of } \\
\text { treatment (months) }\end{array}$ & $\begin{array}{c}\text { Duration of treatment } \\
\text { (months) }\end{array}$ \\
\hline $1 \mathrm{~F}$ & 44 & 88 & 44 \\
\hline $2 \mathrm{~F}$ & 60 & 132 & 72 \\
\hline $3 \mathrm{~F}$ & 50 & 121 & 73 \\
\hline $4 \mathrm{~F}$ & 19 & 120 & 501 \\
\hline $5 \mathrm{~F}$ & 67 & 125 & 69 \\
\hline $6 \mathrm{~F}$ & 56 & 125 & 82 \\
\hline $7 \mathrm{~F}$ & 51 & 133 & 61 \\
\hline $8 \mathrm{M}$ & 81 & 142 & 52 \\
\hline $9 \mathrm{~F}$ & 80 & 132 & $68.0(16.98)$ \\
\hline Mean $(\mathrm{SD})$ & $56.4(19.07)$ & $124.2(15.2)$ & \\
\hline
\end{tabular}

A girl and a boy showed hypothalamic hamartomas on their magnetic resonance imaging (MRI) scans while the others had normal neuro-imaging. Apart from the CPP there were no other neurological manifestations. Treatment was discontinued in one girl at 7 years and 4 months of age due to persistent hypertension (Serial no: 1) after being on treatment for 3 years and 8 months. There was no evidence of local adverse effects. Two girls had benign ovarian serous cysts during treatment needing surgical resection?.

Table 2 is an analysis of the growth in height during the period of treatment demonstrating a significant reduction in the height SDS with therapy $(\mathrm{p}<0.0001)$. Bone age prior to stopping treatment ranged from 112 to 162 months (9yr $4 \mathrm{~m}$ to $13 \mathrm{yr} 6 \mathrm{~m}$ ) with a mean of 138.44 months (approximately $11 \mathrm{yr} 6 \mathrm{~m}$ ). 
Long term outcome of gonadotrophin releasing hormone analogue therapy in Sri Lankan children with central precocious puberty Sri Lanka J. Child Health 2015; 44(2): 82-87

Table 3 gives the outcome of skeletal maturation which confirms a significant reduction in BA acceleration.
Table 4 is an analysis of the height velocities over time with treatment showing a significant progressive reduction with therapy.

Table 2: Effect of therapy on heights of the patients $(n=9)$

\begin{tabular}{|c|c|c|c|c|}
\hline $\begin{array}{l}\text { Serial number } \\
\text { and gender }\end{array}$ & $\begin{array}{c}\text { Pre-treatment } \\
\text { height }(\mathbf{c m})\end{array}$ & $\begin{array}{c}\text { Height at } \\
\text { completion of } \\
\text { treatment (cm) }\end{array}$ & $\begin{array}{c}\text { Pre-treatment } \\
\text { height SDS }\end{array}$ & $\begin{array}{c}\text { Height SDS at } \\
\text { completion of } \\
\text { treatment }\end{array}$ \\
\hline $1 \mathrm{~F}$ & 106.8 & 124.8 & 1.94 & 0.28 \\
\hline $2 \mathrm{~F}$ & 130.0 & 148.2 & 4.72 & 0.59 \\
\hline $3 \mathrm{~F}$ & 108.0 & 130.5 & 1.29 & -1.31 \\
\hline $4 \mathrm{~F}$ & 89.0 & 134.0 & 2.64 & -0.70 \\
\hline $5 \mathrm{~F}$ & 129.0 & 144.1 & 3.45 & 0.50 \\
\hline $6 \mathrm{~F}$ & 120.0 & 144.0 & 3.15 & 0.48 \\
\hline $7 \mathrm{~F}$ & 107.2 & 137.0 & 0.94 & -1.10 \\
\hline $8 \mathrm{M}$ & 138.0 & 155.8 & 3.46 & 1.18 \\
\hline $9 \mathrm{~F}$ & 122.0 & 141.8 & 0.54 & -0.34 \\
\hline Mean $(\mathrm{SD})$ & & & $2.46(1.38)$ & $-0.047(0.85)$ \\
\hline
\end{tabular}

$t=7.93, d f=8, p<0.0001$

Table 3: Outcome of skeletal maturation with treatment $(n=9)$

\begin{tabular}{|c|c|c|c|c|c|c|}
\hline $\begin{array}{l}\text { Serial } \\
\text { number } \\
\text { and gender }\end{array}$ & $\begin{array}{c}\text { Pre-treatment } \\
\text { chronological } \\
\text { age (CA): } \\
\text { months }\end{array}$ & $\begin{array}{c}\text { Pre- } \\
\text { treatment } \\
\text { bone age } \\
\text { (BA): months }\end{array}$ & $\begin{array}{c}\text { Chronological } \\
\text { age (CA) at } \\
\text { last bone age } \\
\text { (BA): months }\end{array}$ & $\begin{array}{c}\text { Last bone } \\
\text { age (BA): } \\
\text { months }\end{array}$ & $\begin{array}{c}\text { Pre- } \\
\text { treatment } \\
\text { skeletal } \\
\text { maturation: } \\
\text { CA/BA }\end{array}$ & $\begin{array}{c}\text { Skeletal } \\
\text { maturation } \\
\text { at final } \\
\text { assessment: } \\
\text { CA/BA }\end{array}$ \\
\hline $1 \mathrm{~F}$ & 44 & 120 & 108 & 162 & 0.37 & 0.67 \\
\hline $2 \mathrm{~F}$ & 60 & 126 & 132 & 132 & 0.48 & 1.00 \\
\hline $3 \mathrm{~F}$ & 50 & 84 & 101 & 132 & 0.60 & 0.77 \\
\hline $4 \mathrm{~F}$ & 19 & 24 & 128 & 120 & 0.79 & 1.07 \\
\hline $5 \mathrm{~F}$ & 67 & 144 & 112 & 112 & 0.47 & 1.00 \\
\hline $6 \mathrm{~F}$ & 56 & 103 & 118 & 132 & 0.54 & 0.89 \\
\hline $7 \mathrm{~F}$ & 51 & 106 & 130 & 162 & 0.48 & 0.80 \\
\hline $8 \mathrm{M}$ & 81 & 132 & 142 & 162 & 0.61 & 0.88 \\
\hline $9 \mathrm{~F}$ & 80 & 106 & 127 & 132 & & 0.75 \\
\hline Mean $(\mathrm{SD})$ & & $105.0(35.22)$ & & 138.44 & 0.5656 & $0.893(0.129)$ \\
\hline
\end{tabular}

Significance of $C A / B A$ measurements $\rightarrow t=5.232, d f=8, p<0.0001$

Table 4: Comparison of the height velocity (cm/year) with treatment $(n=9)$

\begin{tabular}{|c|c|c|c|}
\hline $\begin{array}{l}\text { Serial number and } \\
\text { gender }\end{array}$ & $\begin{array}{c}\text { Pre-treatment height } \\
\text { velocity }\end{array}$ & $\begin{array}{c}\text { Height velocity during } \\
\text { first year of treatment }\end{array}$ & $\begin{array}{c}\text { Height velocity during } \\
\text { last year of treatment }\end{array}$ \\
\hline $1 \mathrm{~F}$ & 9.6 & 9.2 & 3.7 \\
\hline $2 \mathrm{~F}$ & 6.0 & 4.7 & 5.4 \\
\hline $3 \mathrm{~F}$ & 12.6 & 5.5 & 4.8 \\
\hline $4 \mathrm{~F}$ & 19.2 & 4.4 & 4.0 \\
\hline $5 \mathrm{~F}$ & 9.3 & 3.8 & 3.7 \\
\hline $6 \mathrm{~F}$ & 9.0 & 5.0 & 2.3 \\
\hline $7 \mathrm{~F}$ & 6.6 & 6.8 & 4.4 \\
\hline $8 \mathrm{M}$ & 5.0 & 4.8 & 2.2 \\
\hline Mean $\mathrm{FD})$ & 7.2 & 3.7 & 4.8 \\
\hline
\end{tabular}

$F=9.489, p<0.0001$ 
Long term outcome of gonadotrophin releasing hormone analogue therapy in Sri Lankan children with central precocious puberty Sri Lanka J. Child Health 2015; 44(2): 82-87

Time to menarche after stopping treatment $(n=7$ as one girl was lost for follow up after stopping treatment) ranged from 4 months to 43 months (3yr
$7 \mathrm{~m})$ with a mean of 17.6 months (approximately $1 \mathrm{yr}$ $6 \mathrm{~m})$ - Table 5 .

Table 5: Progression of puberty after treatment $(n=7)$

\begin{tabular}{|c|c|c|c|c|}
\hline $\begin{array}{l}\text { Serial number } \\
\text { and gender }\end{array}$ & Age at menarche & $\begin{array}{c}\text { Time to menarche } \\
\text { after stopping } \\
\text { treatment }\end{array}$ & Age when last seen & $\begin{array}{c}\text { Time after } \\
\text { menarche at last } \\
\text { review }\end{array}$ \\
\hline $1 \mathrm{~F}$ & $9 \mathrm{yr} 9 \mathrm{~m}$ & $29 \mathrm{~m}(2 \mathrm{yr} 5 \mathrm{~m})$ & $10 \mathrm{yr} 10 \mathrm{~m}$ & $1 \mathrm{yr} 1 \mathrm{~m}$ \\
\hline $2 \mathrm{~F}$ & $11 \mathrm{yr} 4 \mathrm{~m}$ & $4 \mathrm{~m}$ & $13 \mathrm{yr} 9 \mathrm{~m}$ & $2 \mathrm{yr} 5 \mathrm{~m}$ \\
\hline $3 \mathrm{~F}$ & $13 \mathrm{yr} 8 \mathrm{~m}$ & $43 \mathrm{~m}(3 \mathrm{yr} 7 \mathrm{~m})$ & $13 \mathrm{yr} 9 \mathrm{~m}$ & $1 \mathrm{~m}$ \\
\hline $4 \mathrm{~F}$ & $11 \mathrm{yr} 6 \mathrm{~m}$ & $18 \mathrm{~m}(1 \mathrm{yr} 6 \mathrm{~m})$ & $13 \mathrm{yr} 1 \mathrm{~m}$ & $1 \mathrm{yr} 7 \mathrm{~m}$ \\
\hline $5 \mathrm{~F} *$ & Not known & Not known & $\begin{array}{c}10 \mathrm{yr} 6 \mathrm{~m} \text { (prior to } \\
\text { menarche })\end{array}$ & Not applicable \\
\hline $6 \mathrm{~F}$ & $10 \mathrm{yr} 10 \mathrm{~m}$ & $5 \mathrm{~m}$ & $13 \mathrm{yr} 10 \mathrm{~m}$ & $3 \mathrm{yr}$ \\
\hline $7 \mathrm{~F}$ & $12 \mathrm{yr} 8 \mathrm{~m}$ & $19 \mathrm{~m}(1 \mathrm{yr} 7 \mathrm{~m})$ & $12 \mathrm{yr} 10 \mathrm{~m}$ & $2 \mathrm{~m}$ \\
\hline $8 \mathrm{M}$ & Not applicable & Not applicable & $12 \mathrm{yr} 10 \mathrm{~m}$ & Not applicable \\
\hline $9 \mathrm{~F}$ & $11 \mathrm{yr} 5 \mathrm{~m}$ & $5 \mathrm{~m}$ & $15 \mathrm{yr} 6 \mathrm{~m}$ & $4 \mathrm{yr} 1 \mathrm{~m}$ \\
\hline
\end{tabular}

* Lost for follow up after stopping treatment

Seven patients were within the target height range when last seen and 2 of them had exceeded the target height (Serial numbers 6 and 7). The 2 patients who had not reached the TH range (Serial numbers 1 and 5) had achieved the PMH - Table 6.

Table 6: Heights at last review in relation to predicted mature heights and parents' heights (cm)

\begin{tabular}{|l|c|c|c|c|c|c|}
\hline $\begin{array}{l}\text { Serial } \\
\text { number } \\
\text { and } \\
\text { gender }\end{array}$ & $\begin{array}{c}\text { Father's } \\
\text { height } \mathbf{( c m )}\end{array}$ & $\begin{array}{c}\text { Mother's } \\
\text { height } \mathbf{( c m})\end{array}$ & $\begin{array}{c}\text { Target } \\
\text { height } \mathbf{( c m})\end{array}$ & $\begin{array}{c}\text { Target height range } \\
\text { (cm) }\end{array}$ & $\begin{array}{c}\text { Height } \\
\text { when last } \\
\text { seen }(\mathbf{c m})\end{array}$ & $\begin{array}{c}\text { Predicted } \\
\text { mature } \\
\text { height } \\
\text { (cm) }\end{array}$ \\
\hline 1 F & 165.50 & 151.00 & 151.75 & $143.25-160.25$ & 140.6 & 129.8 \\
\hline 2 F & 165.00 & 152.00 & 152.00 & $143.50-160.50$ & 150.0 & 151.8 \\
\hline 3 F & 160.00 & 154.00 & 150.50 & $142.00-159.00$ & 143.5 & 144.0 \\
\hline 4 F & 167.00 & 154.00 & 154.00 & $145.50-162.50$ & 147.5 & $*$ Not \\
applicable \\
\hline 5 F & 165.00 & 160.00 & 156.00 & $147.50-164.50$ & 144.1 & 144.3 \\
\hline 6 F & 158.50 & 145.10 & 145.30 & $136.80-153.80$ & 147.8 & 142.8 \\
\hline 7 F & 154.00 & 147.00 & 144.00 & $135.50-152.50$ & 145.0 & 137.0 \\
\hline 8 M & 165.00 & 156.50 & 167.25 & $158.75-175.75$ & 160.2 & 179.3 \\
\hline 9 F & 167.00 & 164.00 & 159.00 & $150.50-167.50$ & 152.0 & 156.3 \\
\hline
\end{tabular}

*Predicted mature height could not be calculated as BA was $<7$ years at commencement of treatment

\section{Discussion}

Treatment is indicated for CPP as the physical and psychosocial consequences, if untreated, are devastating for the child and family. Treatment improves auxological outcome and causes regression of puberty and reversal of secondary sexual characteristics $^{3,10}$, thus lessening the psychosocial impact of CPP. A satisfactory auxological outcome with treatment has been reported as a reduction in the height SDS and height velocity, and slowing of skeletal maturation thereby improving the final adult height $^{6,10-13}$. The commonest outcome of therapy appears to be an improvement in the final height compared to the $\mathrm{PMH}$ which is within the $\mathrm{TH}$ range but less than the $\mathrm{TH}^{14,15}$..

Considering the auxological outcome of our patients, we demonstrated a significant reduction in the height SDS (Table $2 \rightarrow \mathrm{t}=7.93, \mathrm{df}=8, \mathrm{p}<0.0001$ ) at completion of treatment with the height velocity reducing significantly with time $(\mathrm{F}=9.489$, $\mathrm{p}<0.0001)$. The skeletal maturation had also reduced significantly at the final assessment compared to pretreatment skeletal maturation (Table $3 \rightarrow \mathrm{t}=5.232$, $\mathrm{df}=8, \mathrm{p}<0.0001)$. 
Long term outcome of gonadotrophin releasing hormone analogue therapy in Sri Lankan children with central precocious puberty Sri Lanka J. Child Health 2015; 44(2): 82-87

Our patients when last seen were aged 10 years 10 months to 15 years 6 months. The timing after menarche at last review was between 1 month and 4 years 1 month (Table 5). Therefore we have only documented the height at last review and not the final adult height (which is defined as a height increment of $<0.5 \mathrm{~cm} /$ year or a bone age $\geq 16$ years in girls and $\geq 18$ years in boys ${ }^{14}$ ). The heights when last seen were within the target height range in 7 patients while 2 children (Serial numbers 6 and 7) had reached the TH and 3 had exceeded the PMH (Serial numbers 1, 6 and 7) - Table 6 . All the girls were $\leq 152 \mathrm{~cm}$ when last seen. But as there is the potential to gain approximately 5.0 to $7.5 \mathrm{~cm}$ after onset of menarche ${ }^{16}$, there is still a possibility that their final height would improve. This would be appropriate for the average adult heights for Sri Lankan men and women of $163.6(6.9) \mathrm{cm}$ and $151.4(6.4) \mathrm{cm}$ respectively $^{17}$.

The maximum final height has been achieved in patients stopping therapy at a BA of 12.0 to 12.5 years ${ }^{1,13}$. The BA in our patients ranged from 9 years 4 months $(112 \mathrm{~m})$ to 13 year 6 months $(162 \mathrm{~m})$ at final assessment with a mean of approximately 11 year 6 months (138.44m \pm 18.94). Our sample (being an analysis of children followed up in one ward) was too small to decide on the optimum time of stopping treatment based on the BA to gain the maximum height.

Although the height achieved at the end of treatment seems acceptable based on the $\mathrm{PMH}$ and $\mathrm{TH}$ range of our patients, the criteria regarding timing of stopping treatment probably needs to be examined afresh in our children. The mean (SD) height velocity during the last year of therapy was $3.92(1.09) \mathrm{cm} /$ year. Although the reduction of height velocity with treatment over the years was significant, the velocity during the last year of treatment was probably inadequate. Therefore, the velocity in relation to BA and CA should be evaluated more closely to give more potential for height gain after stopping therapy.

The mean time to onset of menarche after cessation of treatment in our patients was 17.6 months (approximately 1yr 6m) which is comparable to previous reports ${ }^{3,18,19}$. The time of stopping treatment ${ }^{1,8,19}$ should thus be individualized and, apart from the psycho-social indications, based on the TH, $\mathrm{PMH}$, skeletal maturation and the trend of change of height velocity over time and our experience of time to menarche after cessation of therapy.

\section{Conclusion}

There was a significant reduction in the height SDS, bone age acceleration and height velocity in the cohort of children with CPP treated with a GnRHa.

\section{References}

1 Carel JC, Eugster EA, Rogol A, Ghizzoni L, Palmert MR. Consensus Statement on the use of gonadotropin-releasing hormone analogs in children. Pediatrics 2009; 123(4): e752-e762. http://dx.doi.org/10.1542/peds.2008-1783 PMid:19332438

2 Allali S, Lemaire P, Couto-Silva A, Prete G, Trivin C, Brauner R. Predicting the adult height of girls with central precocious puberty. Medical Science Monitor 2011; 17(6):PH41-48. http://dx.doi.org/10.12659/MSM.881794 PMid:21629198

3 Mul D, Hughes IA. The use of GnRH agonists in precocious puberty European Journal of Endocrinology 2008;159:S3-S8 http://dx.doi.org/10.1530/EJE-08-0814 PMid:19064674

4 Bayley N, Pinneau SR. Tables for predicting adult height from skeletal age: Revised for use with the Greulich-Pyle hand standards. Journal of Pediatrics 1952; 40:423-41 http://dx.doi.org/10.1016/S0022-3476(52)802057

5 Greulich WW, Pyle SI. Radiographic atlas of skeletal development of the hand and wrist $2^{\text {nd }}$ ed. Stanford, CA: Stanford University Press 1959

6 Gomez F, Pico AM, Vargas F, Mauri M. Improvement of expected and final height in girls with central precocious puberty treated with gonadotropin releasing hormone analogues. Med Clin (Barc) 1996; 107(18):681-4

7 Tanner JM, Goldstein H, Whitehouse RH. Standards for children's height at ages 2-9 years allowing for height of parents. Archives of Disease in Childhood 1970; 45:755-62 http://dx.doi.org/10.1136/adc.45.244.755

8 Zacharin M, Banerjee I, Patel L. Puberty: normal and abnormal. In: Margaret Zacharin, editor. Practical Paediatric Endocrinology in a Limited 
Resource Setting. New South Wales: Elsevier 2011.

9 de Silva KSH. Ovarian cysts needing surgical intervention in two girls with central precocious puberty receiving treatment - A case report. $S r i$ Lanka Journal of Child Health 2012; 41(2):93-4 http://dx.doi.org/10.4038/sljch.v41i2.4399

10 Bajpai A, Sharma J, Kabra M, Gupta AK, Menon PS. Long-acting GnRH analogue triptorelin therapy in central isosexual precocious puberty. Indian Pediatrics 2002; 39(7):633-9

11 Kauli R, Galatzer A, Kornreich L, Lazar L, Pertzelan A, Laron Z. Final height of girls with central precocious puberty, untreated versus treated with cyproterone acetate or $\mathrm{GnRH}$ analogue. A comparative study with reevaluation of predictions by Bayley-Pinneau method Hormone Research 1997; 47(2):54-61 http://dx.doi.org/10.1159/000185432 PMid:9030968

12 Galluzzi F, Salti R, Bindi G, Pasquini E, La Cauza C. Adult height comparison between boys and girls with precocious puberty after long-term gonadotrophin-releasing hormone analogue therapy. Acta Paediatr 1998; 87(5):521-7 http://dx.doi.org/10.1111/j.16512227.1998.tb014 97.x

13 Arrigo T, Cisternino M, Galluzzi F, Bertelloni S, Pasquino AM, Antoniazzi F, et al. When to stop GnRH analog therapy: the experience of the Italian Study Group for Physiopathology of Puberty. Journal of Pediatric Endocrinology and Metabolism 2000; 13 Suppl 1:759-64

http://dx.doi.org/10.1515/JPEM.2000.13.S1.759 PMid:10969918

14 Klein KO, Barnes KM, Jones JV, Feuillan PP, Cutler Jr GB. Increased final height in precocious puberty after long-term treatment with LHRH Agonists: The National Institutes of Health Experience. Journal of Pediatric Endocrinology and Metabolism 2001; 86(10): 4711-16 http://dx.doi.org/10.1210/jcem.86.10.7915 PMid:11600530
15 Micillo M, Salerno M, Officioso A et al. Near final height after GnRH agonist treatment in central precocious puberty Journal of Pediatric Endocrinology and Metabolism 2000;13(Suppl 1): 787-90 http://dx.doi.org/10.1515/JPEM.2000.13.S1.787 PMid:10969922

16 Styne DM, Grumbach MM. Puberty: Ontogeny, neuroendocrinology, physiology and disorders. In: Wilson JD, Foster DW, Kronenberg HM, Larsen PR editors. Williams Textbook of Endocrinology, 9th edition. WB Saunders Company, Philadelphia 1998

17 Ranasinghe P, Jayaewardana MA, Constantine GR, Sheriff MH, Matthews DR, Katulanda P. Patterns and correlates of adult height in Sri Lanka. Economics and Human Biology 2011; 9(1):23-9 http://dx.doi.org/10.1016/j.ehb.2010.09.005 PMid:21126931

18 Paterson WF, McNeill E, Young D, Donaldson MD. Auxological outcome and time to menarche following long-acting Goserellin therapy in girls with central precocious or early puberty. Clinical Endocrinology (Oxf) 2004; 61(5):626-34 http://dx.doi.org/10.1111/j.13652265.2004.0214 6.X PMid:15521967

19 Pasquino AM, Pucarelli I, Accardo F, Demraj V, Segni M, Nardo RD. Long-Term Observation of 87 Girls with Idiopathic Central Precocious Puberty Treated with Gonadotropin-Releasing Hormone Analogs: Impact on Adult Height, Body Mass Index, Bone Mineral Content and Reproductive Function. Journal of Pediatric Endocrinology and Metabolism 2008; 93(1):1905.

http://dx.doi.org/10.1210/jc.2007-1216

PMid:17940112 